\title{
A Manaus de Milton Hatoum em Cinzas do norte
}

\author{
Gínia Maria Gomes*
}

\begin{abstract}
Resumo: O ensaio tem como objeto de estudo o romance Cinzas do norte, de Milton Hatoum. Serão discutidos alguns aspectos específicos da modernidade, como o progresso, sob cujo influxo avassalador Manaus não fica imune; a questão da violência, que no regime militar assume um caráter extremamente repressor; e o exame do lugar do artista em uma sociedade que cerceia qualquer posição crítica e contestadora.
\end{abstract}

Palavras-chave: modernidade, progresso, violência, repressão, artista.

\begin{abstract}
This essay has as the main aim of analysis the novel Cinzas do norte, by Milton Hatoum. We will discuss some specifics topics of the modernity, as the progress, which had a large influence in Manaus city's development; the theme of violence that, in the militar period, takes on an extreme repressor aspect; and also the analysis of the artist's place in a society that suppress any critic and contest point of view.
\end{abstract}

Keywords: modernity, progress, violence, repression, artist.

\section{As idiossincrasias da modernidade}

A Manaus representada em Cinzas do norte exibe problemas característicos da cidade moderna. Como na Paris do século XIX, em que ao lado do "luxo da sedutora metrópole nascente" estava aquela "que fedia e que era cheia de ratos" (PESAVENTO, 1999, p.47), a mesma divisão entre ricos e pobres está nitidamente configurada, o que pode ser percebido nos personagens que compõem a trama. De um lado, Jano e seus amigos, os detentores do poder político e econômico da cidade e, de outro, Ramira, que, com suas costuras, luta arduamente para conseguir se sustentar e educar o sobrinho. No entanto, não se pode esquecer da população anônima, que vive em situação miserável, a beira dos fétidos igarapés, presente no romance. Para esses seres sem perspectiva a prostituição certamente é o caminho divisado, o que se nota pela referência a muitas jovens que, para sobreviver, se submetem a essa condição infamante.

A família Mattoso vive em um luxuoso palacete: "O luxo maior vinha de cima: um estuque antigo com figuras de liras, harpas, cavaletes e pincéis" (p.31) ${ }^{1}$ A afirmação não deixa

\footnotetext{
* Gínia Maria Gomes é professora de Literatura Brasileira na UFRGS. Atualmente a autora realiza uma pesquisa sobre a representação da cidade em crônicas e romances

${ }^{1}$ Todas as citações seguem a edição: HATOUM, Milton. Cinzas do norte. SP: Companhia das Letras, 2005.
} 
dúvidas quanto à ostensiva riqueza do casal. No pátio três carros completam o quadro: um DKV, um jipe e um Aero Willys. Além disso, possuem um iate e um apartamento no Rio de Janeiro. Alicia e o filho passam as férias nessa "metrópole". Quando retornam, ela se compraz em estabelecer as diferenças entre as duas cidades: "mas também o prazer íntimo em contrastar o esplendor da metrópole com o marasmo da província” (p.92).

Tal é o poder aquisitivo do casal que, no Rio, ela deixa-se seduzir pela mercadoria, e, num êxtase de consumista voraz, compra muitas coisas, algumas das quais não gosta e outras completamente inúteis:

Abria os pacotes sem parar de beber uísque; dizia com ar de surpresa ou decepção que não sabia por que comprara aquele abajur horroroso, ou o colar de velha, ou o casaco de veludo grená - quem ia usar aquilo num clima tão quente? (p.92)

Mesmo quando os negócios de Jano passam por uma fase difícil, quando a juta não está bem cotada no mercado, a sua condição econômica é amplamente satisfatória: seja em decorrência das amizades com aqueles que ocupam postos no governo, com os quais realiza negócios, como o que havia acertado com o prefeito: "a prefeitura ia comprar juta da Vila Amazônia. Zanda faria isso para ajudá-lo, os dois negociavam” (p.191); seja pela possibilidade de abrir novas frentes: "Palha havia sugerido ao amigo que mudasse de ramo: devia construir casas e edifícios, exportar minérios ou madeira nobre, ou então participar de alguma sociedade com alguma indústria eletrônica da Ásia, muita gente do Sul estava fazendo isso em Manaus" (p.187).

Enquanto Alicia esbanja, inclusive pagando ao motorista por seus serviços extras, com o intuito de acobertar seus encontros clandestinos com o amante, Ramira sacrifica-se para manter uma vida digna. Consegue mudar-se para o centro, na Vila da Ópera, onde compra uma das "cinco casinhas de madeira" (p. 26), feitas pelos operários que construíram "dois casarões geminados" (p.26), ressaltando ainda aqui as diferenças, porque elas "se intrometem como uma cicatriz num quarteirão de sobrados austeros" (p.26); vizinhava, à direita, com uma "mansão moderna", cuja entrada era "vedada" por um "portão de ferro" (p.26). Isso significou uma melhoria em sua vida, porque antes a comunicação com seus clientes era difícil, dada a precariedade do transporte. Com a necessidade de cobrir as despesas da casa, Ramira é mostrada, em geral, no ato de costurar, sabendo aproveitar as épocas propícias da atividade e precaver-se dos meses em que o movimento diminuía. Cabe ressaltar que também ela é seduzida pela mercadoria, mas, ao contrário de Alicia, apenas olha as novidades, que certamente não teria condições de adquirir: "Naquela época em Manaus, quase tudo podia ser importado, e um dos prazeres de minha tia era admirar, em pleno sol da tarde, as vitrines 
repletas de peças de organdi suíço e de seda do oriente e da Itália.” (p.172). O seu olhar assemelha-se ao da família de pobres, em andrajos, do poema "Os olhos dos pobres", de Baudelaire, já que essa, expurgada do centro, a ele retorna. Pára diante de um café e "observa, embevecida, o brilhante mundo novo, lá dentro" (BERMAN, 1986, p.179). A exemplo da família, que olha para aquilo que não pode consumir, também Ramira se deixa seduzir pela novidades expostas nas vitrines.

As diferenças entre as duas famílias da obra estão evidentes não apenas pelas diferentes habitações. A desigualdade está exposta também no tratamento que Jano dispensa ao sobrinho de Ramira. Sabedor das dificuldades por que passam, em duas ocasiões, ele tenta cooptar Lavo. Na primeira, quando vai visitá-los, põe em evidência a situação precária em que eles se encontram: "Vocês estão numa pendura danada, rapaz" (p.37). Depois acena-lhe com a possibilidade de "um dinheirinho a mais!" (p.37). Quando o pai de Mundo vai embora, a consciência da própria situação se impõe: “deixou também uma sensação mais aguda de penúria" (p.38), evidenciando a distância entre os dois mundos. Na outra circunstância ele tenta seduzi-lo com um estágio, o que também é rejeitado pelo narrador.

Em condições ainda mais adversas que a de Ramira estão os índios que, alijados da terra, da qual eram os donos, vieram para a cidade. Nela vivem em estado de extrema miserabilidade. Embora apenas uma família indígena apareça no romance, e de forma passageira, ela pode ser vista como a representação de um problema social mais amplo e, portanto, paradigmático do êxodo do campo para a cidade. Esses indivíduos, sem condições de integrar-se ao mercado de trabalho, acabam marginalizados, sobrevivendo das esmolas que recebem: "quando se afastou vi uma família de índios catando as moedas que [Mundo] jogara" (p.39). Nessa oportunidade Lavo está seguindo o amigo e o encontra na casa de Arana. Quando retornam do atelier do artista, passam novamente pela mesma família, que, sentada no chão, está comendo. O amigo os observa e faz um comentário cáustico, do qual se infere a sua consciência do problema social: "se Jano visse aqueles índios, ia dizer que eram preguiçosos e vagabundos" (p.45). Na possível avaliação de Jano ele descobre o pensamento da ideologia dominante, que faz uma inversão ao considerar "preguiçosos e vagabundos" aqueles a quem não é dado possibilidade de trabalho.

A penúria da população é generalizada. Ela fica mais transparente na viagem para a Vila Amazônia, pelo contraste entre o iate de Jano, "um dos [...] mais luxuosos de Manaus" (p.61), e a pauperização das comunidades que vivem à beira do rio, pelas quais Jano e seus convidados passam. Com uma delas trocam peixes, tartarugas e frutas por "café, sabão, sal, 
açúcar, latas de leite em pó e peças de tecido" (p.63), o que destaca a carência desses povoados.

Há ainda a avassaladora insalubridade dos igarapés, a beira dos quais vive considerável parcela da população. Lavo aponta para esse aspecto: "Olhei para a água barrenta e suja do igarapé, para os casebres, para a gente pobre da beira rio, e pensei no meu amigo em Berlim" (p.230). Logo a seguir, depois de ter recebido uma importância vultuosa de Arana, as condições degradantes se destacam ainda mais ao seu olhar: "O fedor da água e das latrinas dos casebres era insuportável, e aquela quantia, uma aberração na paisagem devastada" (p.231).

É, no entanto, a prostituição de meninas que destaca com maior força o estado miserável da população e suas cenas disseminam-se no texto. As ruas e bares são os locais em que elas vão à caça de clientes. De carona com Jano, o narrador observa: "Perto do Palácio da Justiça, meninas de short e camiseta saíram da sombra dos oitizeiros, lábios vermelhos brilhavam, depois sumiam. Viram o carro preto e avançaram, juntas, para a rua de pedras." (p.34). O carro é o chamariz. À "sombra do oitizeiro" elas aguardam, certamente atentas aos modelos de carro mais modernos, nos quais divisam possibilidades talvez mais promissoras.

Cena abominável é a que ele depara em um bar, no qual a dona, verdadeira cafetina, intermedia uma transação. Meninas de trezes, quatorze anos são oferecidas a Arana. É sob o olhar crítico de Mundo que a ignomínia se desvela: “Conhecem o maior artista do Amazonas? Ele vende quadros por uma fortuna e paga uns trocados pra descabaçar essas meninas.'” (p.149). Essas jovens, oriundas do interior, não têm perspectiva. Mundo ainda faz considerações sobre esse aspecto: "Podiam estar na Vila Amazônia, ralando mandioca. Aqui é melhor, se divertem um pouco, ganham uns trocados de Arana...” (p.150) Sem chances no interior, na cidade a prostituição é o caminho que se lhes oferece.

Outras cenas de prostituição são apresentadas. Uma delas é quando, na viagem para a Vila Amazônia, socorrem um barco cujo motor estava com problema. Ao se aproximar, o narrador informa: "Era um barco cheio de meninas e com uns quatro homens" (p.65). Dois dos homens são nomeados: Zanda e seu ajudante, vulgo "Heródoto". A descrição é deprimente: políticos eminentes, abastados, enchem o barco de meninas para um passeio no rio... Alguns anos depois, Lavo encontra uma delas no Mercado Adolpho Lisboa e ela o reconhece. $\mathrm{Na}$ ocasião, ele está com o tio que ainda observa a situação dessas mulheres: "Essas guerreiras dão um duro danado pra encher o bucho" (p 271). O trágico é que as meninas "guerreiam" para sobreviver, sem nenhuma perspectiva de sair dessa situação, fato que o reencontro deixa transparente. 
Assim como em Paris e no Rio de Janeiro, também Manaus, com sua população pobre vivendo em condições insalubres à beira dos igarapés, submete-se a um processo de modernização ${ }^{2}$. Em Cinzas do norte, não há uma data precisa, mas é por volta de 1970 que há um grande influxo de progresso ${ }^{3}$, em que "reformas urbanas" foram realizadas de forma indiscriminada, o que está explícito nas palavras do narrador, que reproduz o olhar crítico do tio: “apenas escarnecia do coronel Zanda, que, depois de ter destruído parte de Manaus e de sua história com a mania insana de modernização e reforma urbana, se reformara e morava no Rio”(p.301-302).

Certamente o principal exemplo dessa modernização é o projeto Novo Eldorado que consistia na construção de casas afastadas do centro e do rio, para deslocar aqueles que moravam a sua margem, isto é, os moradores de palafitas que viviam próximos ao porto, em condições insalubres. A imagem dessa população contrapunha-se ao projeto de uma cidade moderna, porque descobria um retrato da pobreza, expondo suas mazelas. Para fazer essa limpeza o prefeito construíu o Novo Eldorado. O nome é sugestivo. O leitor desavisado, conhecedor do mito ${ }^{4}$, pode criar expectativas, que logo se desvanecem, pois na perspectiva de Mundo, o projeto revela sua verdadeira face. Lugar afastado do centro, cuja natureza fora devastada: “'Os moradores da beira do rio. Foram lançados no outro lado da cidade. A área foi toda desmatada, construíram uma casas... Sobrou uma seringueira. Quer dizer, o tronco e uns galhos... a carcaça."” (p.144). A expressão "foram lançados” mostra a arbitrariedade do ato. Mais adiante, os problemas do local são enunciados com clareza: "Casinhas sem fossa, um fedor medonho. Os moradores reclamavam: tinham que pagar para morar mal, longe do centro, longe de tudo... Queriam voltar para perto do rio. [...] Os moradores do Novo Eldorado eram prisioneiros em sua própria cidade" (p.148). Esses problemas apontados por Mundo são também verbalizados pela mãe de Cará, que ainda acrescenta alguns outros: "Reclamou do Novo Eldorado: faltava água e luz, o banheiro não tinha fossa, os moradores jogavam o lixo perto da mata, aí os bichos vinham comer naquele chiqueiro" (p.178). As palavras de Ranulfo, proferidas para os moradores, também apontam para a precariedade do local: "Vocês foram enganados; prometeram tudo, e olha só que lugar triste... triste e longe do

\footnotetext{
2 “A modernidade - expressão artística e intelectual de um projeto histórico chamado 'modernização' e produzido pela transformação capitalista de mundo - dá nascimento à experiência, também histórica, individual e coletiva, do "viver em metrópole"” (PESAVENTO, 1999, p.30)

${ }^{3}$ Em Dois irmãos, Milton Hatoum apresenta a destruição da Cidade Flutuante, realizada logo depois do golpe militar, com o intuito de fazer a limpeza da cidade.

4 "O mito do Homem dourado, habitante de um vale plantado com árvores de canela às margens de um lago de águas verdes" (NOUHAUD, 1997, p. 315 - verbete Eldorado), fora evocado por Voltaire em Essais sur le moeurs e em Candido (cf. NOUHAUD).
} 
porto..." (p.211). O projeto fora um engodo para aquelas pessoas, transferidas para um lugar distante e sem as mínimas condições sanitárias, sem água e sem luz. Mas o centro fora limpo, a população pobre fora expurgada e não mais importava em que condições estavam vivendo, os problemas que agora enfrentavam, pois a pobreza que expunha suas mazelas não mais compunha o retrato do centro da cidade.

Outra faceta do progresso está na destruição dos prédios antigos para a construção de outros, mais modernos e sofisticados, ou para a abertura de avenidas:

Em poucos anos Manaus crescera tanto que Mundo não reconheceria certos bairros. Ele só presenciara o começo da destruição; não chegara a ver a 'reforma urbana' do coronel Zanda, as praças do centro, como a Nove de Novembro, serem rasgadas por avenidas e terem todos os seus monumentos saqueados. Não viu sua casa ser demolida, nem o hotel gigantesco erguido no mesmo lugar. (p.258-259)

A avassaladora "reforma urbana" realizada em Manaus tem no trinômio "circulação, higiene e estética" (PESAVENTO, 1999, p.168) o seu moto condutor. Segue os passos de Paris, cujo "empreendimento pôs abaixo centenas de edifícios, deslocou milhares e milhares de pessoas, destruiu bairros inteiros que aí tinham existido por séculos” (BERMAN, 1986, p. 172). A cidade francesa que, na virada do século, fora exemplo para o Rio de Janeiro, que destrói seus "becos, ruelas e ruas tortuosas", cedendo espaço à "vias mais amplas, claras e arejadas" (PESAVENTO, 1999, 175), sem esquecer da demolição de prédios que não se enquadravam em um dos termos do trinômio. Com isso a população pobre foi afastada do centro, posto que, na perspectiva da elite, "era suja e perigosa" (PESAVENTO, 1999, p.176). Em Manaus, sob o influxo da modernidade, configura-se uma circunstância similar a que já ocorrera em outras cidades. Ao retirar seus pobres do centro, abrir largas avenidas, destruir e construir, está em sintonia com a frase de Marx, apropriada por Berman: "Tudo o que é sólido desmancha no ar" (1986, p. 15).

\section{A violência institucionalizada}

Em Cinzas do norte a violência está presente no Estado repressor e nos seus Aparelhos Ideológicos (cf. ALTHUSSER, 1984). O núcleo fundamental da trama se situa entre abril de 1964 e dezembro de 1973, portanto, na época da ditadura instaurada pelo golpe militar. Regime de extrema repressão não admite vozes contrárias, às quais persegue, encarcera, tortura e, muitas vezes, mata. Embora as referências ao período ${ }^{5}$ estejam marcadas, os atos de violência só aparecem de forma esporádica, tangenciados em diálogos e comentários. Em uma

\footnotetext{
${ }^{5}$ Mundo vai para o ginásio Pedro II, em abril, “depois do golpe militar” (p. 12). No aniversário do pai, um dos convidados elogia o "novo general-presidente" e "recita um poema em homenagem ao marechal morto." (p.47)
} 
ocasião o narrador faz uma breve observação sobre um estudante que fora morto em São Paulo, sem emitir nenhum juízo de valor:

No meio da semana seguinte, as aulas da faculdade de direito foram canceladas em protesto contra o assassinato de um aluno da Escola Politécnica da Universidade de São Paulo. A imprensa falara pouco e de forma obscura, mas os informes enviados pela Ordem dos Advogados acusavam os militares. (p.122)

O texto permite ao leitor inferir que as vozes dissonantes eram caladas e a imprensa censurada. Em outra ocasião, Ranulfo relata ao sobrinho um caso de guerrilha na cidade, o que ele desconhecia: "Na faculdade discutíamos atrocidades do governo em outros lugares, mas ninguém tinha falado sobre esse grupo em Manaus" (p.129). Os participantes foram presos, torturados e "o chefe foi encarcerado em Belém e depois executado" (p.129). Este é mais um episódio para mostrar que qualquer oposição ao regime era silenciada. Esses dois fatos, que aparecem no romance, permitem mostrar a violência do regime militar. Esta, embora se direcionasse à toda a sociedade, está no texto representada pelos estudantes e pelos guerrilheiros, porque talvez eles fossem os grupos mais bem organizados, o que lhes permitiu fazer oposição acirrada ao governo. Os demais se constituíram em vozes isoladas, que ou eram caladas ou buscavam o exílio, ou seja, de alguma forma emudeciam.

Em Cinzas do norte a escola reproduz a mesma violência do Estado. A repressão se impõe nas regras a que os alunos devem se sujeitar, sob pena de sofrerem castigos; a agressão explícita transparece nos "Jogos de Arena". O que deveria ser uma saudável competição, transforma-se em uma brincadeira mortal, em que vence o mais forte, o mais agressivo. Em um desses jogos, um aluno morre enquanto o vencedor, em estado de êxtase, sequer percebe que matou o companheiro. A expulsão do culpado não dilui a agressividade dos estudantes, ao contrário, acirra-a:

Em novembro, depois de um processo que não deu em nada, o veterano foi expulso do Pedro II, os jogos recomeçaram ainda mais violentos: lutadores que prometiam vinganças e apontavam as barras de ferro retorcidas, evocando a valentia do amigo punido, e os covardes que se cuidassem. (p.15-16)

A agressão que, segundo Althusser, é prerrogativa fundamental do Estado, enquanto os Aparelhos Ideológicos se fundam principalmente na ideologia (cf. 1985, p.70), no romance, a equação está invertida, porque também na escola a hostilidade está generalizada. Esses jogos são sintomáticos do ambiente geral, talvez a metáfora das relações interpessoais nas diversas instâncias.

Mundo é uma das vítimas da opressão escolar. No ginásio Pedro II, além de não se adequar às regras, as quais constantemente subverte, "enraivecendo os bedéis" (p.14), ele tinha nas caricaturas uma forma de resistência. Nelas ele expunha os colegas ao ridículo, em 
evidente posição crítica. Também, na escola, sua crítica não era aceita, por isso desencadeava atitudes agressivas nos colegas. Ultrajados, eles prepararam uma brincadeira, expondo-o ao ridículo: "Minotauro colou com carrapicho um chumaço de rabiola na traseira do artista, tocou fogo com álcool e se afastou;" (p.18). Não fora ele atirar-se imediatamente na água, talvez a brincadeira pudesse assumir proporções trágicas. Mundo foi silenciado, pois apesar do seu bom rendimento, afastou-se da escola, sem prestar os exames finais.

O Colégio Militar não fica atrás. O melhor exemplo é Cará vítima de violência por ser oriundo das camadas desprivilegiadas da população: "O Cará era tratado como bicho, mangavam dele o tempo todo.” (p. 174). Embora Mundo não faça muitos comentários sobre os treinamentos na selva, ele deixa transparecer o extremo rigor a que eram submetidos.

À violência do Estado e da escola, soma-se aquela que ocorre no âmbito familiar. Aqui, quem a sofre é Mundo, que tem na figura paterna um verdadeiro carrasco. Aos cinco anos de idade, o seu castigo é ficar aprisionado no porão. Não conformar-se às regras, mesmo quando ainda não podia compreendê-las, tinha como conseqüência imediata ser encaminhado para esse local escuro, certamente, desesperador para alguém com apenas cinco anos. As perguntas que dirige à mãe apontam nesse sentido: "Perguntavas a tua mãe por que tudo era tão escuro e por que agora só escutavas o barulho da chuva e das trovoadas e por que tinhas que comer sozinho e só podias sair à noite pra ir dormir no quarto, e ela, tua mãe, não sabia o que dizer" (p.252). Também o desenho do "rosto de uma criança gritando" (p.252) confirma o seu estado emocional. A violência praticada pelo pai também se configura na negativa de olhar os desenhos que o filho tenta lhe mostrar; ao não permitir que ele brinque com as crianças pobres, habitantes das palafitas, ou com os filhos dos empregados. Condená-lo à solidão é uma crueldade, porque a criança ainda não tinha capacidade de entender os castigos que lhe eram impostos.

A violência de Jano não tem limite. Na medida em que o filho cresce, ele muda as suas táticas, recorrendo então à agressividade física. Quanto mais deseja ajustar o filho aos seus padrões, às suas regras, mais o filho tenta subvertê-los, procurando a cada passo colocar-se em franca oposição ao progenitor. Através de seus atos e palavras, Mundo procura contrariar o pai, gerando reações de agressividade física. Em um desses episódios, na presença do narrador, Mundo verbaliza a sua opinião sobre um dos amigos do pai, chamando-o de "grande vigarista". Segue-se a reação imediata de Jano: "o cinturão do pai atingira o pescoço de Mundo; a outra lambada açoitou seus ombros" (p.121). O amigo sai de casa e Lavo vai procurá-lo. Encontra o motorista, Macau, que esclarece: "Essas lapadas do patrão vêm de muito longe" (p.122). 
A relação entre pai e filho entra num ciclo vicioso: o pai o agride, o filho, em contrapartida, realiza atos também agressivos, porque põem em xeque a ordem estabelecida e destroem os sonhos paternos. É o caso de sua passagem pelo Colégio Militar. Enquanto o pai esperava que ele se formasse, inclusive organizando uma festa na Vila Amazônia para comemorar a efeméride, o filho falsificava assinaturas e planejava inaugurar o Campo de Cruzes, sua obra de arte, que visava descobrir as mazelas do Novo Eldorado. Nessa obra, o Eldorado transforma-se em cemitério. A reação imediata do pai é queimar todos os livros, quadros, desenhos, enfim, tudo o que era significativo para o filho.

Jano não aceita a alteridade representada pelo filho. Antes mesmo de seu nascimento ele cria a expectativa de um "herdeiro", ou seja, aquele que continuaria a sua própria trajetória, o seu próprio caminho. Mundo, ao manifestar pendor artístico, põe em xeque os sonhos paternos. Se o pai vê no filho alguém que contraria o seu desejo de continuidade, Mundo vê no pai aquele que cerceia a sua própria realização. A afirmação de Roger Dadoun está adequada a cada um deles: "é a partir do outro que ameaças, agressões, hostilidades e duros golpes nos atingem, fundamentando-se em nós" (1998, p.63).

\section{O lugar do artista}

Em Cinzas do norte o artista tem um papel de destaque, representado nas figuras de Arana e de Mundo, cujas criações e posições ideológicas divergem. Um assume a "obediência estúpida" (p.10) ao status quo, enquanto o outro opta pela "rebeldia" (p.10), que também constitui o norte de sua própria vida.

É interessante perseguir inicialmente a trajetória de Mundo, porque é principalmente nas discussões com o pai que a apreciação negativa da arte se impõe. Nele a vocação, que se manifesta desde a infância, tem no pai um ferrenho opositor. Empresário bem-sucedido, a sua visão da arte é a dominante na cidade moderna, pelo menos, é a dos que ocupam um lugar privilegiado na pirâmide social. Por seu caráter não-utilitário e pelas dificuldade de o artista chegar ao sucesso e a uma posição econômica privilegiada, a arte é desprezada e o seu criador considerado um vagabundo. A avaliação depreciativa de Jano é posta com clareza. São muitas as ocasiões em que se manifesta contrário à tendência artística do filho. Em conversa com Lavo, quando este lhe expõe que o amigo só fala em arte, ele imediatamente observa: “Por isso é que não promete nada, Jano interrompeu. Arte... quem ele pensa que é?'” (p.22). Observa-se o mesmo menosprezo em outra circunstância: “Queria passar o tempo todo 
desenhando. É um vício, uma doença...” (p.32) Agora, o comentário é ainda mais cáustico, porque enquadra a habilidade de Mundo como "vício" e "doença".

Quando Jano toma conhecimento de que o filho ficou em Parintins "trabalhando" na preparação dos festejos, ele, substituindo o verbo, não deixa dúvidas quanto ao que pensa: "Vadiando, isso sim" (p.76). Essa qualidade não é prerrogativa de Mundo. Referindo-se a Arana, recorre a termos similares: “Ainda não conheces? Um vagabundo. Um pintor de trambolhos sem pé nem cabeça. Também faz esculturas... coisas tortas, tudo porcaria!"” (p.36). Por outro lado, não é apenas ele que tem tal visão da arte e do artista, Palha também a tem e se pode considerá-la paradigmática daquela que permeia esse meio social. Conversando com Mundo, aconselha-o a trilhar o caminho do pai e de seus amigos: “'É como empresário ou político, e não como artista, que vais sair da obscuridade comum. E para isso é preciso estudar"” (p.119). Complementando a observação de Palha, Jano manifesta, mais uma vez, o extremo desprestígio do artista: “Tu e os artistas... uns inúteis.” (p.120). A voz popular referenda essa perspectiva preconceituosa, pois, no seu velório, ouvem-se cochichos: "Diz que é vadio, quer ser artista..." (p.206)

Conhecida a visão da arte e do artista naquela sociedade, endossada por Jano, não surpreende o leitor o seu desejo de afastar o filho desse caminho, tentando mesmo reprimir a sua vocação. No entanto, ao fazê-lo, excede-se no zelo. Diante do filho de apenas cinco anos, sem olhar para os desenhos que ele lhe apresenta, talvez para não o estimular, pergunta-lhe: “"É só isso que sabes fazer?”” (p.252). A reação paterna é tão marcante que, horas mais tarde, tendo fugido para a rua, é encontrado chorando, desejoso de mostrar os desenhos ao pai.

Essa insensibilidade de Jano e conseqüente incapacidade de compreender e aceitar o filho será motivadora dos conflitos futuros. Com o transcorrer do tempo, eles não são contemporizados, ao contrário, a passagem dos anos com o crescimento de Mundo torna-os ainda mais acirrados. $\mathrm{O}$ choro dos cinco anos transforma-se no destemido confronto dos vinte e um, no qual o filho desabafa toda a sua verve, reprimida ao longo do tempo. Ambos têm na arte o moto condutor do desequilíbrio. Se aos cinco o pai sequer olha os desenhos do filho, aos vinte e um ele é obrigado a tomar conhecimento de sua obra, porque o Campo de Cruzes ${ }^{6}$ é objeto, inclusive, de notícia de jornal. Arte contestatória, de denúncia, coloca em xeque o status quo ao mostrar a verdadeira face do Novo Eldorado.

Entre esses dois extremos, a vocação artística de Mundo se impõe e, apesar da injunção paterna, ele não deixa de persegui-la. Os desenhos são a sua forma de expressão e o

\footnotetext{
${ }^{6}$ O Campo de Cruzes consistia de cruzes colocadas em frente de cada uma das casas do Novo Eldorado. Os moradores ficavam deitados e, nesse sentido, dava a impressão de um cemitério.
} 
meio de captar o instante, mostrando o quanto, desde muito cedo, está consciente da realidade histórica repressiva inaugurada pelo golpe militar, o que sua caricatura do "marechalpresidente" indica (p.16).

A recepção de Campo de Cruzes é interessante para mostrar a total impossibilidade de uma arte contestatória e criativa naquela conjuntura histórico-social. Não se pode esquecer que o presidente da República era Médice, cujo governo caracterizou-se pela extrema repressão. Não há, pois, espaço para a contestação, imediatamente reprimida, sendo o artista perseguido, como ocorre com Mundo, que necessitou se esconder para não ser punido. As agruras sofridas desde a infância no âmbito familiar apenas prefiguram aquelas impostas por uma sociedade repressora, na qual a arte que contesta a ordem não tem espaço. O Campo de Cruzes inaugura e, ao mesmo tempo, fecha a trajetória de Mundo no Brasil. Ele segue para a Europa, com o objetivo de fazer uma carreira artística. Apesar de seus esforços, não consegue expor os seus trabalhos e nem freqüentar nenhuma escola de arte, como desejava. Contudo, a sua arte vai aprimorando-se. Depois de sua morte, a herança que deixa para a mãe, passa a ser valorizada. Um "marchand de Ipanema” (p.289) se interessa por ela, e Alicia a vende aos poucos, por uma importância não revelada, mas, ao que tudo indica, razoável. Embora não se saiba a importância recebida, parece que a venda de aquarelas e quadros lhe dá um novo alento, podendo-se inferir que, de alguma forma, a sua obra estava sendo valorizada.

Mundo só consegue realizar a sua obra máxima, a seqüência de sete quadros que pinta quando está na Europa, depois de romper com o mestre. É interessante sua consciência de que não existe originalidade total: “Arana bem que tentou inocular na minha cabeça o veneno de uma 'arte amazônica autêntica e pura', mas agora estou imunizado contra as suas preleções. Nada é puro, autêntico, original...” (p. 238) A observação de Mundo mostra o seu alargamento de horizontes, do que decorre sua maior compreensão do fenômeno artístico, do processo mimético. Ao afirmar que "nada é puro, autêntico, original" ele está em sintonia com uma discussão de extrema importância na história da arte, que as palavras de Arnold Hauser confirmam:

Se tivéssemos de apresentar um critério geral do que constitui a arte, poderíamos pensar em dizer: a originalidade. Mas não existe semelhante critério. Dificilmente poderemos fazer qualquer afirmação sobre arte sem que tenhamos que admitir, num ou noutro contexto, precisamente o contrário. (1988, p. 319).

Se a originalidade total não existe, o estudioso mostra que é necessário de alguma forma buscá-la: "uma obra de arte deve exprimir a sua própria concepção do mundo, nova e específica se tiver de ter algum valor em si própria, e na verdade alguma qualidade estética" (HAUSER, 1988, p. 319). Parece que é justamente essa concepção que está no cerne daquilo 
que Mundo busca: "Planejo desenvolver uma obra sobre a Vila Amazônia. Quero usar a roupa e os dejetos do meu pai. Uma idéia que tive em Berlim, quando andava pelo Tiergarten..." (p.238)

Lavo, além de observar a "técnica apurada" (p.295), compreende que os quadros “traduziam a angústia de Mundo e eram o presságio de sua própria morte” (p.294). É através de Lavo que o leitor toma conhecimento da temática dessa obra. A figura do pai, central no primeiro quadro, vai-se decompondo até desaparecer nos últimos:

Os farrapos da roupa usada pelo homem no primeiro quadro, que havia sido rasgada, cortada e picotada; na última, o par de sapatos pretos cravados com pregos que ocupavam toda a tela, os sapatos voltados para direções opostas (p. 293).

A história do pai pode ser lida como a história da falência de um modelo econômico, na medida em que trabalhadores da Vila Amazônia estão presentes no primeiro quadro. Enfim, é também a sua própria história, o que as palavras do narrador apontam. Neste sentido, as palavras de Benjamin sobre a autenticidade e originalidade da obra de arte, elementos que desaparecem nas reproduções, são apropriadas para analisar esta seqüência: "O que caracteriza a autenticidade de uma coisa é tudo aquilo que ela contém e é originalmente transmissível desde sua duração até seu poder de testemunho histórico" (1983, p. 6).

$\mathrm{Na}$ última carta que envia ao amigo e que fecha o romance, ele reflete sobre a criação do quadro, sobre as dificuldades e impasses enfrentados. Ao fazê-lo, sua reflexão põe o leitor diante do processo criativo, cujos temas, embora calcados em personagens de sua vida, sobretudo no pai, são reinventados e, por isso mesmo, afastam-se da produção naturalista:

Passei semanas no sobrado da Villa Road, sem sair, pintando dia e noite, destruindo e pintando
outra vez, tentando encontrar a imagem em seu instante de plenitude. Não sei quanta coisa veio
do acaso, quanta coisa veio dos estudos e esboços, esse difícil equilíbrio entre o acaso e a
intenção. O que sei é que trabalhei de maneira exasperada, alucinada às vezes, às vezes rindo
da minha própria desgraça. Formas mais ou menos figurativas, decompondo o retrato da
família, até chegar à roupa e aos dejetos de Jano. Idéias e emoções que nos movem. Me livrei
de um peso quando terminei esse trabalho, mas não me considero um artista, Lavo. Só quis dar
algum sentido a minha vida." (p.307)

Ironicamente, ao terminar essa sequiência, ápice de sua carreira, ele "não [se] consider[a] um artista." Ora, esses quadros são destruídos por Alicia que, desde a primeira vez que os viu, sentiu-se incomodada. Compreende-se que embora ela não esteja explicitamente neles representada, a história de Jano é de alguma forma também a sua e o olhar do filho, que apresenta a degradação do pai, talvez seja um espelho de sua própria decadência. A destruição de sua obra máxima significou também a destruição do artista, como disse Ranulfo: "seria a mesma coisa que matar Mundo" (p. 249), o que, a mãe acaba efetivamente fazendo. 
Destruídos, os quadros que deveriam representar o artista em sua maturidade e, como tal, dar-lhe um espaço, impõem-lhe o esquecimento. Justamente a única obra a que Mundo se dedicou, trabalhando efetivamente nela. Enquanto estava na Europa, Mundo realizou inúmeros trabalhos, mas, apesar disso, não conseguiu fazer nenhuma exposição, o que lhe daria um outro status. Como artista, ele mesmo vai ao mercado vender seu trabalho. Abordava as pessoas e

"perguntava com a maior cara-de-pau: Não gostarias de decorar te quarto tua sala com um desenho ou aquarela?' alguns compravam, talvez por comiseração, e eu embolsava cinco, oito libras, e ia comprar tubos de tinta, papel e tela. E assim eu empurrava desenhos e aquarelas aos clientes da Wallpaper Center ou os oferecia em bares e restaurantes, como fazia na Alemanha. (p.246)

É uma situação ultrajante, da qual não consegue se eximir. Como o flaneur baudelairiano, ele vai ao mercado: "Pensa que é para dar uma olhada nele; na verdade, porém, já para encontrar um comprador" (BENJAMIN, 1985, p.39). No entanto, constata-se uma grande diferença entre ambos: a posição de Mundo é agressiva em relação aos seus possíveis compradores, enquanto a do flaneur é mais sutil, porquanto ele finge não estar buscando um comprador.

A trajetória de Arana é a da "obediência", embora nos primórdios de sua carreira tenha optado por uma arte criativa, que tentava fugir da reprodução da natureza amazônica. Quando ele é apresentado ao leitor está vendendo objetos aos turistas; talvez as estatuetas que ele comprava de Pai Jobel por um preço ínfimo e depois as revendia por uma importância bem maior. Não é revelado ao leitor o percurso desse artista; só se tem conhecimento de sua vida através das visitas feitas pelo narrador ao seu atelier, quando observa suas obras, e dos comentários de Mundo. Momento de contestação é quando ele idealiza uma jaula e nela coloca ossos e capim seco.

Porém, esta fase é logo substituída por uma arte ao gosto do público, de acordo com o horizonte de expectativas e, portanto, vendável, a qual é amplamente criticada por Mundo e pelo narrador. Ao seguir outro caminho, ele está contrariando tudo o que ensinou ao discípulo. Olhando uma pintura, Lavo comenta: "Parece pintura de um naturalista ou viajante', comentei. 'Não é o contrário do que ensinaste para Mundo?'” O outro desculpa-se: ““È um quadro encomendado’ justificou ele” (p.131). O fato de escusar-se mostra que está vivendo um momento de transição; não estando ainda totalmente seguro desse novo direcionamento. Caso contrário, não teria sentido a explicação de que o quadro não fora fruto de uma inspiração. Mais adiante, Mundo comenta essa posição de Arana: ““Arana renegou até aquela jaula queimada cheia de ossos e capim seco... Dizia que era uma obra muito crítica, 
mas hoje acha que é fútil. Uma fase experimental, já passou... Falou assim mesmo, e ainda riu. Arana virou um reles comerciante de arte."' (p.164). Cooptado pelo sistema, sob encomenda, ele passa a pintar a natureza amazônica: "Não perguntei do que se tratava: bastou olhar as fotos coloridas de araras numa parede. Duas, de asas abertas, cresciam numa tela, e prometiam voar num céu dourado que iluminava a floresta." (p.164). A crítica corrosiva de Mundo, que o chama de "pintorzinho de floresta" (p. 170), demonstra o quanto ele havia se desvirtuado daquela perspectiva que seduzira o jovem artista. Olhar arguto, sempre atento às transformações e expectativas dos compradores, passa a usar o mogno na criação de animais inexpressivos e a pintar quadros exóticos, cuja "técnica não era menos impecável que o exotismo" (p.227).

Quase no final do romance, o narrador, ao visitar Palha, surpreende-se com um quadro de Arana aliado ao empreendimento imobiliário do empresário: "Ao me virar, vi a parede coberta por um painel pintado com araras. Imensas, sobrevoavam um amontoado de torres de vidro e concreto no horizonte desmatado. A visão alucinada e grotesca da floresta, e talvez do futuro me arrepiou" (p.264). O quadro representa, de forma enfática essa transformação modernizante pela qual a cidade está passando. Palha comenta a origem do quadro: "Nossa empresa encomendou esse quadro a um artista... Arana', disse Palha. 'Um pintor talentoso.'” (p.264).

As duas atribuições que Arana recebe, a de Jano, que o desclassifica com a pecha de "vagabundo", e a de Palha, que o elogia com o predicado de "pintor talentoso", marcam os diferentes momentos de sua trajetória artística. A "obediência estúpida" às expectativas dos compradores, embora com o sacrifício da criatividade, abre-lhe espaço no mercado, fazendo com que tanto seus quadros quanto ele sejam valorizados. Ao contrário, Mundo não se curva e, ao trilhar o caminho da "rebeldia", em uma sociedade sob o domínio de um Estado repressivo, as portas se fecham, e ele tem que sair de Manaus e do País, porque sua obra contestadora não tem espaço. "Obediência" e "rebeldia" marcam as respectivas trajetórias e são responsáveis pela aceitação daquele que se ajusta às exigências do mercado e pela rejeição do outro, que se rebela contra elas.

\section{0 término do passeio}

Certamente as reflexões não esgotam o potencial do romance. Há uma forte presença da cidade física, sinalizada pelos nomes dos bairros, ruas, praças, igarapés. Algumas dessa marcas fazem parte de um passado, que sucumbiu ao progresso, como a maioria dos igarapés 
que, em nome da modernização, transformaram-se em avenidas. Outras, no entanto, permaneceram e podem ser encontradas na Manaus do século XXI. Os espaços físicos são constantemente nomeados, e poderíamos seguir outros caminhos, mas deixemos ao leitor o prazer de percorrê-los sozinho, escolhendo as trilhas para realizar o seu próprio passeio...

\section{Referências}

ALTHUSSER, Louis. Aparelhos ideológicos do Estado.i Rio de Janeiro: Edições Graal, 1985.

BENJAMIN, Walter. A obra de arte na época de sua reprodutibilidade técnica. In: BENJAMIN, Walter, HORKHEIMER, Max, ADORNO, Theodor, HABERMAS, Jürgen. Textos escolhidos. São Paulo: Abril Cultural, 1983.

BENJAMIN, Walter. Paris capital do século XIX. In: Ática, 1985. . Walter Benjamin. São Paulo

BERMAN, Marshall. Tudo o que é sólido desmancha no ar: a aventura da modernidade. São Paulo: Companhia das Letras, 1986.

DADOUN, Roger. A violencia: ensaio acerca do "homo violens". Rio de Janeiro: DIFEL, 1998.

HATOUM, Milton. Cinzas do norte. São Paulo: Companhia das Letras, 2005.

HAUSER, Arnold. Teorias da arte. Lisboa: Editorial Presença, 1988.

NOUHAUD, Dorita. Eldorado. In: BRUNEL, Pierre (Org.) Dicionário de mitos literários. Rio de Janeiro: José Olympio, 1997.

PESAVENTO, Sandra Jatahy. O imaginário da cidade: visões literárias do urbano - Paris, Rio de Janeiro, Porto Alegre. Porto Alegre: Ed. da Universidade / UFRGS, 1999. 